\section{Grafting Fraser Fir (Abies fraseri): Effect of Grafting Date, Shade, and Irrigation}

\author{
Haley Hibbert-Frey ${ }^{1}$, John Frampton ${ }^{2,4}$, Frank A. Blazich ${ }^{3}$, \\ and L. Eric Hinesley ${ }^{3}$ \\ Department of Forestry and Environmental Resources, North Carolina State \\ University, 3219 Jordan Hall, Raleigh, NC 27695-8008
}

Additional index words. Abies bornmuelleriana, Christmas trees, Phytophthora cinnamomi, rootstock, scion, vegetative propagation

\begin{abstract}
Grafting fraser fir [Abies fraseri (Pursh) Poir.] scions onto rootstocks of turkish fir (Abies bornmuelleriana Mattf.) is a strategy used by some Christmas tree growers in the southern Appalachian Mountains of North Carolina to reduce losses by phytophthora root rot caused by Phytophthora cinnamomi Rands. This study compared the traditional time of grafting (April) with eight summer/early fall grafting dates from mid-July through midOctober. Shade and irrigation treatments were also superimposed on the grafting dates. To ensure optimal grafting success, grafting should be performed in the late winter/early spring (April) when scions are dormant and the rootstocks are becoming active. April graft success was $95 \%$ but when grafting fresh scions in summer/fall, graft success decreased from $52 \%$ in July to $0 \%$ in October. Shade improved summer graft success $(52 \%$ with, $\mathbf{3 8 \%}$ without). Irrigation did not significantly affect graft success or subsequent growth. In a supplemental storage study, grafting of stored scion material in summer/early fall was not successful (less than $1 \%$ ).
\end{abstract}

Fraser fir is one of the most popular Christmas tree species in the United States and is indigenous to isolated mountain tops at elevations between 1370 and $2037 \mathrm{~m}$ in southwestern Virginia, western North Carolina, and eastern Tennessee (Liu, 1971). Christmas tree plantations of this species are scattered throughout the southern Appalachian region where Christmas tree sales provide an important economic resource. In 2006, revenue from Christmas tree sales in North Carolina totaled \$134 million (U.S. Department of Agriculture, Economic Research Services, 2007). Fraser fir is grown for its fragrance, soft dark green needles, strong branches, excellent needle retention, and natural Christmas tree shape (Frampton, 2001).

Received for publication 29 Oct. 2009. Accepted for publication $19 \mathrm{Jan} .2010$.

This research was funded in part by the North Carolina Agricultural Research Service (NCARS), Raleigh, NC, through the Christmas Tree Genetics Program.

Use of trade names in this publication does not imply endorsement by the NCARS of products named nor criticism of similar ones not mentioned. Technical assistance of Avery County IPM Technician, Doug Hundley, and Avery County Extension Director, Jerry Moody, is gratefully acknowledged. We also thank Avery County Christmas tree grower, Benny Vance, for use of his land and Christmas trees, Fikret Isik for statistical assistance, and Josh King for irrigation design and supplies.

This research is from a MS thesis by the senior author.

${ }^{1}$ Former Graduate Research Assistant.

${ }^{2}$ Professor.

${ }^{3}$ Professor, Department of Horticultural Science.

${ }^{4}$ To whom reprint requests should be addressed; e-mail john_frampton@ncsu.edu.
Phytophthora cinnamomi, the primary cause of phytophthora root rot, has spread rapidly throughout soils in western North Carolina causing large economic losses. Once a site is infested, the pathogen is nearly impossible to eradicate. Fraser fir seedlings can die within 2 or 3 weeks from infection (Benson et al., 1998). Thus, there is a large demand in the region for planting stock that is resistant to, or tolerant of, this pathogen. To ameliorate the impact of this disease, some Christmas tree growers in the region are grafting fraser fir onto rootstocks of more resistant fir (Abies Mill.) species. Grafting onto resistant rootstocks is a widely accepted method of managing phytophthora root rot (Hinesley and Frampton, 2002). In a controlled inoculation study (Benson et al., 1998), momi fir (A. firma Sieb. et Zucc.) was the most resistant species to $P$. cinnamomi. Although it is the favored Abies rootstock species for phytophthora resistance, it is not planted for Christmas tree production because it has undesirable sharp, prickly, light green needles and breaks bud early leaving it extremely susceptible to late frosts. Turkish fir (Abies bornmuelleriana) was less resistant than momi fir (Benson et al., 1998) but has desirable Christmas tree qualities. Furthermore, because momi fir transplants are in short supply most years (as was the case for this study), turkish fir is the next best rootstock choice.

Fraser fir is usually grafted in early spring (April), when the rootstock and scion are dormant, but this is a busy time for growers. The opportunity to graft at other times of the year, e.g., late summer or early fall, would allow Christmas tree growers more flexibility. The objectives of this investigation were to 1) compare success and growth of grafting fresh fraser fir scions onto turkish fir rootstocks during the traditional time of grafting (April) with eight biweekly grafting dates from mid-July through mid-October; 2) assess the effect of shade and irrigation treatments on graft success and growth; and 3) evaluate grafting (mid-July through midOctober) using dormant fraser fir scions collected during April and stored at $-1{ }^{\circ} \mathrm{C}$.

\section{Materials and Methods}

Design of the study. This study was conducted at the North Carolina Division of Forest Resources Linville River Nursery near Crossnore, NC (long. $36^{\circ} 0^{\prime} 31^{\prime \prime} \mathrm{N}$, lat. $81^{\circ} 55^{\prime} 60^{\prime \prime}$ W). In Apr. 2007, one thousand 3-1 (grown 3 years in the seed bed; 1 year grown in the transplant bed) turkish fir rootstocks were planted $\approx 20 \mathrm{~cm}$ apart in raised, freshly tilled $1.2-\mathrm{m}$ wide raised nursery beds in the flood plain of the Linville River. The soil was in the Crossnore-Jeffery soil series (mixed mesic, Umbric Dystrochrepts). The rootstocks were planted in four blocks with each block consisting of three treatment plots of 50 rootstocks and one plot of 100 rootstocks. The smaller plots were $2 \mathrm{~m}$ long ( 10 rows $\times$ five columns of rootstocks). The larger plots included a supplemental study and were $4 \mathrm{~m}$ long with 20 rows and five rootstocks in each column.

Main study. The main study was a randomized complete block design with a $2 \times 2$ factorial arrangement of treatments. There were two shade treatments (shade and no shade) and two irrigation treatments (irrigation and no irrigation).

The smaller plots were for shade + no irrigation, no shade + irrigation, and shade + irrigation treatments, whereas the larger plots accommodated the control (no shade + no irrigation) treatment. On 6 Apr. and then every 2 weeks starting 14 July 2007 through 20 Oct. 2007, single cleft grafts (Garner, 1979; Hinesley and Frampton, 2002) were made with freshly collected scions. On each grafting date, terminal shoots (primary axes) were collected from 80 actively growing fraser fir trees from a Christmas tree farm near Crossnore, NC. The trees were from an unknown provenance, had been growing in the field for 3 years, and were 0.7 to $1.3 \mathrm{~m}$ in height. Scions averaged $10 \mathrm{~cm}$ in length and were $\approx 1 \mathrm{~cm}$ in diameter. Five grafts were randomly assigned to each of 16 plots for each of the eight grafting dates. The grafts were secured with grafting rubber bands $(20 \times 1 \mathrm{~cm})$ and then sealed with Doc Farwell's Grafting Seal (Farwell Products, LLC, Wenatchee, WA).

Supplemental storage study. A supplemental study was simultaneously conducted to investigate the use of stored dormant scions for grafting. The supplemental study also used a randomized complete block design but was established only in the no shade + no irrigation (control) treatment plots, which also accommodated grafts for the main study. The fraser fir scions (200 terminal shoots) used for the supplemental study were collected 6 Apr. 2007 from the same Christmas tree plantation 
used for the main study. Twenty dormant scions were grafted randomly in the four control plots (five in each). The remaining 180 dormant scions were then placed in a plastic bag, the bag placed in a cooler, and the cooler was stored at $-1{ }^{\circ} \mathrm{C}$. For each grafting date in the main study, 20 stored dormant fraser fir scions were grafted onto randomly assigned turkish fir rootstocks in the four control plots.

Shade and irrigation treatments. Shade and irrigation treatments were installed 10 July 2007. Water from a nearby building passed through a filter and then a 2-cm diameter garden hose $67 \mathrm{~m}$ to the study beds. Four 2-m long Netafim drip line hoses (Netafim Ltd., Tel Aviv, Israel) (emitters spaced $30 \mathrm{~cm}$ apart) were run the length of each irrigated plot with the emitters arranged in a staggered pattern. A pressure gauge was installed at the end of the main polyvinyl chloride (PVC) line to monitor water pressure. Irrigation flow rate for one emitter was measured at $465 \mathrm{~mL} \cdot \mathrm{h}^{-1}$.

Shade treatments were initially installed using $2.5-\mathrm{cm}$ rebar frames and $40 \%$ shadecloth. New shade tents were installed 28 July 2007 to provide more room for the rootstocks to grow. Three PVC arches were constructed in each shade plot and covered with $40 \%$ shadecloth to ground level on all sides. A 2.5$\mathrm{cm}$ diameter plastic rain gauge was installed next to the main irrigation valve, and rainfall was recorded twice weekly. If weekly rainfall did not total $25 \mathrm{~mm}$, the irrigation was turned on to provide that amount.

Irrigation was discontinued 28 Oct. 2007 and shade removed 8 Nov. 2007. The grafts were left to overwinter in the beds. Beginning 8 May 2008, grafts were checked for budbreak every $2 \mathrm{~d}$ until all budbreak stopped (16 June 2008). Shade and irrigation treatments were again resumed 13 May 2008. On 3 Aug. 2008 , the following data were collected for each successful graft: leader (scion) elongation (centimeters), longest lateral branch elongation (centimeters), number of original scion buds (terminal and subterminal) broken, number of new lateral buds on the leader (elongated scion), and number of lateral buds per decimeter of the elongated scion.

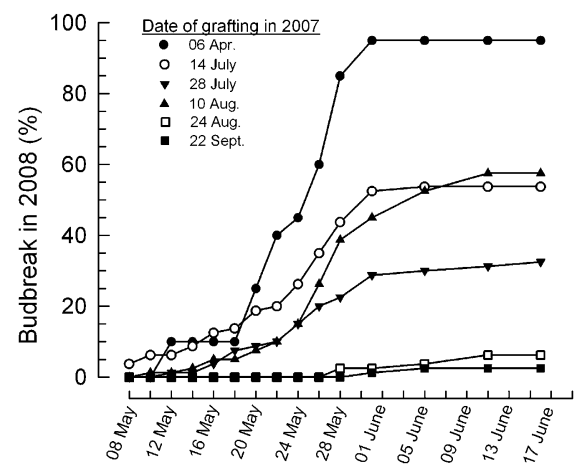

Date in 2008

Fig. 1. Timing of budbreak in 2008 of fraser fir scions grafted onto turkish fir rootstocks on six dates in 2007 near Crossnore, NC (main study). (The 6 Oct. graft date is not shown because all values were zero.)
Statistical analysis. Except for graft success, data were analyzed for only the successful grafting dates (6 Apr., 14 July, 28 July, and 10 Aug.) for the main study using Proc GLM (SAS Institute, Inc., 2003), and all effects were considered fixed. Analyses of variance (ANOVAs) were conducted to test for differences $(P \leq 0.05)$ among main effects (block, date, shade, and irrigation) and all possible interactions for leader elongation, number of scion buds (terminal and subterminal) broken, length of longest lateral branch, number of lateral buds on the leader, and number of lateral buds per stem length. Least squared means were used for comparisons. Because there were no significant interactions for any growth characteristics, interaction terms were removed from the model.

For the binomial response variable (graft success), a generalized linear model with a logistic link function was performed with Proc GENMOD (SAS Institute, Inc., 2003) using the same classification variables used in the ANOVA for continuous variables. It was necessary to omit all interaction effects from the model to achieve convergence for the response variable. Type III likelihood ratio statistics were used to evaluate effect differences. When detected, a Wald $\chi^{2}$ test was used to assess differences among least squares means.

The supplemental storage study was a randomized complete block design. Data (except graft success) were analyzed for only the successful grafting dates using Proc GLM, and all variables were fixed. ANOVAs were conducted to test for differences $(P \leq 0.05)$ among main effects (block and date) for leader elongation, number of scion buds (terminal and subterminal) broken, longest lateral length, number of lateral buds on the leader, and number of lateral buds per stem length. Least squared means were used for comparisons. Because there were no significant interactions for any growth measurements, interaction terms were removed from the model. The bi- nomial response variable (graft success) was analyzed using a generalized linear model with a logistic link function in Proc GENMOD. Again, it was necessary to remove all interactions from the model to achieve convergence for the response variable.

\section{Results}

Main study. Effect of grafting date was significant for graft success, mean leader elongation, longest lateral bud elongation, and number of lateral buds on the leader. Graft success was low (30\% to $52 \%$ ) for the first three summer grafting dates and unsuccessful from 24 Aug. through 20 Oct. Unsuccessful summer grafting dates were not included in the ANOVAs for the other response variables.

Grafting date affected date of budbreak. Scions grafted 14 July 2007 first started breaking bud 8 May 2008 (Fig. 1), whereas those grafted 6 Apr., 28 July, and 10 Aug. 2007 started breaking 10 May 2008. The pattern of budbreak for the four successful grafting dates (6 Apr., 14 July, 28 July, and 10 Aug.) was similar; they all peaked around 1 June 2008, although they all had different degrees of graft success. (Note that in Fig. 1, budbreak for the 6 Apr. date is for the second year of growth after grafting because these grafts broke bud the first year.)

Shade increased $(P \leq 0.05)$ graft success but did not affect other variables measured (Table 1). Plots with the shade treatment had a success rate of $52 \%$ compared with $38 \%$ without shade (Table 2). There were no significant shade $\times$ irrigation interactions.

Supplemental storage study. Grafting date significantly affected $(P \leq 0.05)$ graft success, mean leader elongation, percentage of scion buds broken, mean lateral elongation, and number of newly formed lateral buds on the leader (Table 3). Graft success was 95\% in April, 55\% for the first summer grafting date (14 July 2007), $30 \%$ for 28 July 2007 ,

Table 1. Analysis of variance for successful fraser fir scions grafted onto turkish fir rootstocks 14 July, 28 July, and 10 Aug. 2007 near Crossnore, NC (main study). ${ }^{\mathrm{z}}$

\begin{tabular}{lccccccr}
\hline Source & df & Success & $\begin{array}{c}\text { Leader } \\
\text { (scion) length }\end{array}$ & $\begin{array}{c}\text { No. scion } \\
\text { buds broken }\end{array}$ & $\begin{array}{c}\text { Lateral } \\
\text { length }\end{array}$ & $\begin{array}{c}\text { No. lateral } \\
\text { buds }\end{array}$ & $\begin{array}{r}\text { No. lateral } \\
\text { buds/length }\end{array}$ \\
\hline Block & 3 & NS & $*$ & NS & NS & NS & $*$ \\
Grafting date & 2 & $*$ & $*$ & NS & $*$ & $*$ & NS \\
Shade & 1 & $*$ & NS & NS & NS & NS & NS \\
Irrigation & 1 & NS & NS & NS & NS & NS & NS \\
\hline
\end{tabular}

zThere were no significant interactions.

Ns, * Nonsignificant or significant at $P \leq 0.05$, respectively.

Table 2. Least square means of successful fraser fir scions grafted onto turkish fir rootstocks 14 July, 28 July, and 10 Aug. 2007 near Crossnore, NC (main study).

\begin{tabular}{lcccccc}
\hline & \multicolumn{3}{c}{ Grafting date $^{z}$} & & \multicolumn{2}{c}{ Shade } \\
\cline { 2 - 3 } \cline { 5 - 6 } Growth measurements & 14 July 2007 & 28 July 2007 & 10 Aug. 2007 & & No shade & Shade \\
\hline Success (\%) & $52 \mathrm{~b}$ & $30 \mathrm{a}$ & $52 \mathrm{~b}$ & 38 & 52 \\
Leader (scion) length (cm) & $14.2 \mathrm{a}$ & $20.1 \mathrm{~b}$ & $27.9 \mathrm{~b}$ & & NS & NS \\
Lateral length (cm) & $8.9 \mathrm{a}$ & $10.2 \mathrm{a}$ & $14.2 \mathrm{~b}$ & & NS & NS \\
Lateral buds (no.) & $6.2 \mathrm{a}$ & $7.7 \mathrm{a}$ & $11.7 \mathrm{~b}$ & $\mathrm{NS}$ & NS \\
Lateral buds/length (no./dm) & NS & NS & NS & NS & NS \\
\hline
\end{tabular}

${ }^{\mathrm{z} F o r}$ grafting date, any two means within a row followed by the same letter are not significantly different at $P \leq 0.05$ according to a Wald $\chi^{2}$ test.

Ns, Nonsignificant at $P \leq 0.05$. 
and 50\% for 10 Aug. 2007 (Table 4). Grafting in summer/early fall using stored dormant scion material was not successful $(0 \%$ for all dates).

Similarly, grafting date also affected mean leader elongation and mean lateral elongation. The April grafting date had the shortest elongation with $11.7 \mathrm{~cm}$ for mean leader length and $9.9 \mathrm{~cm}$ for mean lateral elongation (Table 4). For both growth measurements, mean elongation increased for later grafting dates.

The number of scion buds broken was highest (6.1) for the April grafting date and decreased with later grafting dates (Table 4). In the control plots, the mean number of lateral buds formed on the leader was lower for the first two grafting dates (5.9 and 5.8 for 6 Apr. 2007 and 14 July 2007, respectively) and increased for later dates.

\section{Discussion}

Date of grafting significantly affected success ( $0 \%$ to $95 \%)$. Grafting during April when scions were dormant and rootstocks were just becoming active yielded the highest success (95\%) (Table 4). These results agree with current practices for grafting fraser fir (Blazich and Hinesely, 1994; Hinesley and Frampton, 2002) as well as many other conifers, e.g., slash pine (Pinus elliottii Englem.) (Mergen, 1955) and douglas fir [Pseudotsuga menziesii (Mirb.) Franco] (Copes, 1973). Grafting during mid-July through mid-August resulted in modest success rates (30\% to $55 \%$ ) and might potentially be a useful time to graft, particularly if further research and experience could increase success rates. Grafting after midAugust almost completely failed.

The scions of some grafts started breaking bud almost 2 weeks before budbreak (22 May 2008) of the trees from which the scion material was collected. This difference could be the result of site variation, the younger age of the rootstocks, or the rootstock species (turkish fir). A clarification of the relative influence of these potential causes is needed because late spring frosts can result in severe shoot damage during some years (Emerson et al., 2006).

Shoot growth of scions was also affected by grafting date; the later the date of grafting, the greater the elongation (Tables 2 and 4). Mean leader growth in 2008 for the successful summer grafting dates in 2007 increased with time from 14.2 to $27.9 \mathrm{~cm}$ and was $35.3 \mathrm{~cm}$ for the 24 Aug. grafting date, which was excluded from analyses as a result of its low success rate (less than 1\%). A similar pattern occurred for elongation of lateral shoots. Apparently, scion buds were more developed at later collection dates resulting in more growth the next year. Enhanced shoot growth provides another incentive to improve grafting success during late summer. Averaged across the irrigation and shade treatments, leader elongation of grafts performed during the summer was considerably longer than first-year elongation of grafts made in April $(12.8 \mathrm{~cm})$, the latter having had fully developed dormant buds at the time of grafting. Perhaps, increased leader growth is an advantage of separating graft union formation from elongation as occurred in the summer grafts, but it could also be the result of weather differences between the 2 years when elongation occurred.

Weather likely also influenced grafting results. Ambient temperature can reduce or increase grafting success, e.g., douglas fir (Copes, 1973). Above-optimum temperatures can hinder development of graft unions and reduce success rates (Karadeniz, 2005; MacDonald, 1986). During much of Aug. 2007, maximum daily temperatures exceeded optimal temperatures for fraser fir growth (Fig. 2) (Hinesley, 1981). Starting mid-September, both day maximum and night minimum temperatures were below optimum. Apparently, scions grafted after mid-August did not have sufficient cambial activity for the 3 to 4 weeks necessary to form a successful graft union. Water stress can also affect graft success (Beeson and Proebsting, 1988). Failure of grafts can be the result of the inability of the scions to receive water from the rootstocks before the graft union has formed (Barnett and Weatherhead, 1989;
Mergen, 1955). In the present investigation, weekly rainfall was sufficient $(25 \mathrm{~mm}$ or greater) for all but 4 weeks of the 14-week study. When weekly rainfall was not sufficient (weeks of 11 Aug., 10 Sept., 24 Sept., and 9 Oct.), supplemental irrigation provided the difference for irrigation treatments only. Irrigation, however, did not affect graft success or any growth measurements (Table 1) suggesting water availability was not a primary factor contributing to graft success. Presumably, irrigation would prove beneficial to graft success and subsequent development during a drought year.

Besides changing environmental conditions, the physiological condition of both the scions and rootstocks was also changing. The effect of seasonal development on subsequent scion elongation has already been mentioned. Additionally, the rootstocks, which had already broken bud and fully elongated, were hardening off and transitioning into dormancy during the grafting period.

The use of stored dormant scion material in the summer or fall was investigated in the supplemental study. In addition to its

Table 3. Analysis of variance for successful fraser fir scions grafted onto turkish fir rootstocks in control plots during 2007 near Crossnore, NC. ${ }^{\mathrm{z}}$

\begin{tabular}{lccccccc}
\hline Source & df & Success & $\begin{array}{c}\text { Leader } \\
\text { (scion) length }\end{array}$ & $\begin{array}{c}\text { No. scion } \\
\text { buds broken }\end{array}$ & $\begin{array}{c}\text { Lateral } \\
\text { length }\end{array}$ & $\begin{array}{c}\text { No. lateral } \\
\text { buds }\end{array}$ & $\begin{array}{r}\text { No. lateral } \\
\text { buds/length }\end{array}$ \\
\hline Block & 3 & NS & NS & NS & NS & $*$ & NS \\
Date & 3 & $*$ & $*$ & $*$ & $*$ & $*$ & NS \\
\hline
\end{tabular}

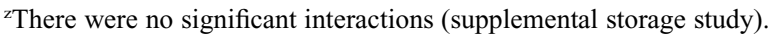

Ns, * Nonsignificant or significant at $P \leq 0.05$, respectively.

Table 4. Least square mean comparisons for successful fraser fir scions grafted onto turkish fir rootstocks in control plots during 2007 near Crossnore, NC (supplemental storage study).

\begin{tabular}{lcccc}
\hline & \multicolumn{4}{c}{ Date (2007) } \\
\cline { 2 - 5 } Growth measurements & 6 Apr. & 14 July & 28 July & 10 Aug. \\
Success (\%) (overall) & $95 \mathrm{a}$ & $55 \mathrm{~b}$ & $30 \mathrm{~b}$ & $50 \mathrm{~b}$ \\
Success (\%) (dormant grafts) & 95 & 0 & 0 & 0 \\
Success (\%) (nondormant grafts) & $\mathrm{NA}$ & 55 & 30 & 50 \\
Leader (scion) length (cm) & $11.7 \mathrm{a}$ & $15.0 \mathrm{ab}$ & $21.1 \mathrm{~b}$ & $28.7 \mathrm{~b}$ \\
Lateral length (cm) & $9.9 \mathrm{a}$ & $9.9 \mathrm{a}$ & $10.4 \mathrm{ab}$ & $11.7 \mathrm{~b}$ \\
Lateral buds (no.) & $5.9 \mathrm{a}$ & $5.8 \mathrm{a}$ & $8.7 \mathrm{ab}$ & $10.5 \mathrm{~b}$ \\
Scion buds broken (no.) & $6.1 \mathrm{a}$ & $5.3 \mathrm{bc}$ & $4.9 \mathrm{ac}$ & $5.0 \mathrm{bc}$ \\
\hline
\end{tabular}

${ }^{2}$ Any two means within a row followed by the same letter are not significantly different at $P \leq 0.05$ according to a Wald $\chi^{2}$ test.

$\mathrm{NA}=$ not applicable.

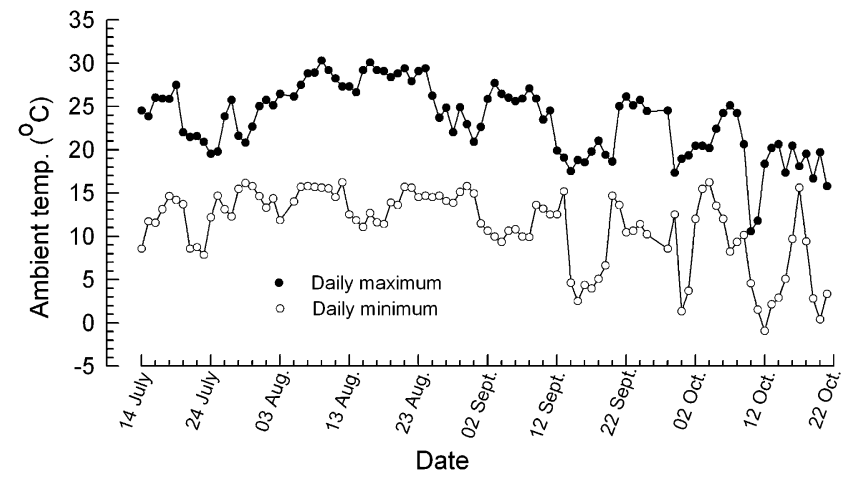

Fig. 2. Daily minimum and maximum temperatures in Crossnore, NC, for July through Oct. 2007 (provided by http://averyweather.com/Archive/Crossnore). Day temperatures of 22 to $27^{\circ} \mathrm{C}$ and night temperatures of 13 to $19^{\circ} \mathrm{C}$ are optimal for growth of fraser fir seedlings (Hinesley, 1981). 
potential practical value, this material could have also served as a control, i.e., a common physiological state of scion material across grafting dates. Unfortunately, none of the grafts involving stored dormant scions was successful. That scion material was stored 14 to 28 weeks in a plastic bag in a $-1{ }^{\circ} \mathrm{C}$ cold room. Based on the authors' experiences, however, dormant fraser fir scions can be held 2 to 3 weeks, especially at -2 to $4{ }^{\circ} \mathrm{C}$ with no adverse effects. Until more successful techniques can be developed, it is prudent to graft fraser fir in early spring with freshly collected dormant scion material.

\section{Literature Cited}

Barnett, J.R. and I. Weatherhead. 1989. The effect of scion water potential on graft success in Sitka spruce (Picea sitchensis). Ann. Bot. (Lond.) 64:9-12.

Beeson, R.C. and W.M. Proebsting. 1988. Relationship between transpiration and water potential in grafted scions of Picea. Physiol. Plant. 74:481-486.

Benson, D.M., L.E. Hinesley, J. Frampton, and K.C. Parker. 1998. Evaluation of six Abies species to Phytophthora root rot caused by Phytophthora cinnamomi. Biological and Cultural Tests for Control of Plant Diseases 13:57-58.

Blazich, F.A. and L.E. Hinesely. 1994. Propagation of fraser fir. J. Environ. Hort. 12:112-117.

Copes, D.L. 1973. Effect of month of grafting on douglas-fir graft compatibility. Res. Note 208. U.S. Dept. Agr. Forest Serv. Pacific Northwest Expt. Sta., Portland, OR.

Emerson, J., J. Frampton, and S. McKeand. 2006. Genetic variation of spring frost damage in 3year-old fraser fir Christmas tree plantations. HortScience 41:1-6.

Frampton, J. 2001. North Carolina's Christmas tree genetics program. Proc. 26th Southern Forest Tree Improvement Conf., Athens, GA, 26-29 June 2001

Garner, R.J. 1979. The grafter's handbook. Oxford Univ. Press, New York, NY.
Hinesley, E. and J. Frampton. 2002. Grafting fraser fir onto rootstock of selected Abies species. HortScience 37:815-818.

Hinesley, L.E. 1981. Initial growth of fraser fir seedlings at different day/night temperatures. For. Sci. 27:545-550.

Karadeniz, T. 2005. Relationship between graft success and climatic values in walnut (Juglans regia L.). J. Central European Agr. 6:631-634.

Liu, T.-S. 1971. A monograph of the genus Abies. Dept. For., College of Agr., Natl. Taiwan Univ., Taipei, Taiwan, Republic of China.

MacDonald, B. 1986. Practical woody plant propagation for nursery growers. Vol. 1. Timber Press, Portland, OR.

Mergen, F. 1955. Grafting slash pine in the field and in the greenhouse. J. For. 53:836-842.

SAS Institute, Inc. 2003. SAS OnlineDoc $®$, Version 9. SAS Inst., Inc., Cary, NC.

U.S. Department of Agriculture, Economic Research Services. 2007. Amber waves-Did you know? Bull. 19 Oct. 2009. <http://www.ers.usda.gov/ AmberWaves/November07/PDF/DidYouKnow. pdf $>$. 